\title{
IMPACT OF ECONOMIC REFORMS ON GST IN INDIA-AN ANALYSIS (WITH REFERENCE TO MANUFACTURERS, DISTRIBUTOR AND RETAILERS)
}

\section{Dr. N. Thyagaraju}

Assistant Professor, Department of Commerce, SRI A.B.R Government Degree College, Repalle, GUNTUR Dt-5222265.

ABSTRACT

This paper is a brief description of the historical scenario of Indian taxation and its tax structure. Then why there is a need for the change in tax structure from traditional system to GST model. There are mixed response, inexplicit, arguments and opinions among the Manufactures, traders and society about the Goods and Services Tax (GST) to be implemented by Government of India from lstApril 2017 this year. Various news organizations from all around the world focused on the bill unifyingthe country and it being an achievement of the government. Evolution of GST has be detailed discuss in this paper as the background, silent features, challenges, revenues, distribution of revenues ,Problems, efforts of government, various GSt Council meetings, Different tax rates etc. The implementation of a comprehensive GST in India is expected to lead to efficient allocation of factors of production thus leading to gains in GDP and exports. Though a number of initiatives by the various machineries at the Centre, the present taxation regime is marked as cumbersome, complicated and unfriendly.

KEYWORDS : Tax structure, Value Added Tax, Central Value Added Tax, Goods and Services Tax, one nation one taxGross domestic Product. Indian economy, Rajya Sabha, Global economy

\section{INTRODUCTION :}

The Goods and Services Tax (GST), considered as the most profound reform in India's indirect taxation system finally becomes a reality. GST anticipates that the tax base will be with minimum exemptions. The main expectation from GST is to eliminate all indirect taxes and only GST would be levied. As the name suggests, the GST will be levied both on goods and services. GST is heralded as a unified system of taxation by which the economy will take on upward swing. GST is a tax imposed on multiple industries, specifically for manufacturing, sale and consumption on goods and services. This tax will be a substitute for almost all indirect taxes by the State Government and Central Government. GST was recommended by Kelkar Taskforce in 2004. According to the Taskforce, an all India GST would be in the nature of a revolution in India's indirect Tax structure since independence because GST would merge all Indirect Taxes imposed by the centre and states ,so there is one country ,one single Indirect Tax. As such GST would substantially bring down cascading burden of various Indirect Taxes Imposed by centre and state together which falls on a final consumer. Most importantly, GST would be a destination based Tax imposed on final consumption wherever a commodity is sold or a service is rendered. It has been proposed that GST revenues shall be shared between the centre and states as all other Indirect Taxes would be subsumed in GST.

\section{OBJECTIVES OF THE STUDY:}

- To study the Need for the GST and the impact of GST on Indian economy.

- To study the advantages GST. and to know the challenges for implementation of GST

- To know the tax revenues through GST

- To give suitable suggestions on the basis of the findings of the study

\section{HYPOTHESIS OF THE STUDY}

There is no association between socio-economic profile of the different sectors of Manufacturing and service sectors in India for implementation of GST

\section{LITERATURE REVIEW}

This section covers the review of literature of some of the important studies, research papers and articles on the various aspects of GST System. Garg (2014) focused on the impact of GST (Goods and Services tax) with a brief description of the historical scenario of Indian taxation and its tax structure and discussed the possible challenges, threats and opportunities that GST brings to strengthen our free market economy. Shah (2014) highlighted the objectives of proposed GST and discussed the possible challenges, threats and opportunities that GST bring before is to strengthen our force marked economy.

- Almost all countries that have established the Goods and Services Tax (GST) system adopt the consumption-type GST in which all purchases of capital goods from other firms are deductible from a firm's sale.

\section{GST ENSURES VALUE-ADDITION ACROSS THE CHAIN MANUFACTURER:}

The manufacturer spends a total of Rs 100 on various raw materials, which is inclusive of the taxes of say Rs 10 he has paid. After $\mathrm{X}$ is manufactured, there is a value addition, of say Rs 40 , making the gross value of the product to be Rs 140 . If the tax charged at the good $\mathrm{X}$ is $10 \%$, the tax on the output of the good will be Rs 14 .

\section{Wholesaler :}

The next stage is when $\mathrm{X}$ moves from manufacturer to the wholesaler and he purchases $\mathrm{X}$ is for Rs 140 . He adds value to $\mathrm{X}$ of say Rs 30; this amount basically constitutes the profit margin. The gross value of X now becomes Rs $170(140+30)$. The total tax at $10 \%$ now equals Rs 17 .

\section{Retailer :}

In the final stage when the product $\mathrm{X}$ reaches the retailer. The retailer adds a margin of Rs 20 and the final price of $X$ now amounts to Rs $190(170+20)$. The tax of $10 \%$ on the gross amount now equal Rs 19 .

\section{Total Tax Incidence :}

In non-GST regime, the total tax incidence is $\mathrm{Rs} 34.62$ $(14.00+18.40+2.22)$. Whereas in GST regime, the total tax incidence on the value addition across the chain from the input suppliers of raw materials to the final retailers is Rs $23(14+4+3+2)$. Hence the tax reduces to Rs 12.62 (34.6222.00)

\section{End-user:}

In GST regime, the final price of $X$ now becomes Rs193, the price at which the customer buys $X$, which includes a tax of Rs 23. In the current non-GST regime, the customer pays 224.40 which includes a tax of Rs 34.62 . 
LATEST GST RATES REVISION IN 37TH GST COUNCIL MEETING

GST Council had its 37th meet held at Goa on Friday (20th September 2019). Read all the highlights on 37th GST Council Meeting. The following are the rate cuts announced at the 36 th GST Council meeting:

GST RATE REVISION EFFECTIVE FROM 1 OCTOBER 2019

\begin{tabular}{|l|l|l|}
\hline Item & $\begin{array}{l}\text { Current } \\
\text { Rate }\end{array}$ & New Rate \\
\hline $\begin{array}{l}\text { Plates and cups made of flowers, leaves } \\
\text { and bark }\end{array}$ & $5 \%$ & Nil \\
\hline Caffeinated Beverages & $18 \%$ & $\begin{array}{l}28 \%+12 \\
\% \text { cess }\end{array}$ \\
\hline $\begin{array}{l}\text { Supplies of Railways wagons \& coaches } \\
\text { (without refund of accumulated ITC) }\end{array}$ & $12 \%$ \\
\hline Outdoor Catering (without ITC) & $18 \%$ & $5 \%$ \\
\hline Diamond Job work & $5 \%$ & $1.50 \%$ \\
\hline Other Job work & $18 \%$ & $12 \%$ \\
\hline Hotels (Room Tariff of Rs.750l or above) & $28 \%$ & $18 \%$ \\
\hline $\begin{array}{l}\text { Hotels (Room Tariff from Rs l,00l to Rs } \\
7,500 \text { ) }\end{array}$ & $18 \%$ & $12 \%$ \\
\hline $\begin{array}{l}\text { Woven/ Non-woven Polyethylene } \\
\text { Packaging bags }\end{array}$ & $18 \%$ & $12 \%$ \\
\hline Marine fuel & $18 \%$ & $5 \%$ \\
\hline Almond Milk & $18 \%$ & $12 \%$ \\
\hline Slide fasteners & $12 \%$ & $5 \%$ \\
\hline $\begin{array}{l}\text { Wet grinders (consisting of stone as a } \\
\text { grinder) }\end{array}$ & $12 \%$ \\
\hline Dried Tamarind & $5 \%$ & Nil \\
\hline Semi-precious stones- cut \& polished & $3 \%$ & $0.25 \%$ \\
\hline $\begin{array}{l}\text { Specified goods for petroleum } \\
\text { operation under HELP* }\end{array}$ & $\begin{array}{l}\text { Applica } \\
\text { ble Rate }\end{array}$ & $5 \%$ \\
\hline
\end{tabular}

\section{GST Exemption available for:}

- Supplies to FIFA- specified persons for the Under-17 Women's Football World Cup in India

- Supply to the Food and Agriculture Organisation (FAO) for specified projects in India

- Imports of certain defence goods not made indigenously (up to 2024)

- Supply of silver/platinum by specified agencies (Diamond India Ltd) for export

- Import of Silver or Platinum by specified agencies (Diamond India Ltd

\section{CHALLENGES BEFORE INDIA'S LARGEST INDIRECT TAX REFORM-GST}

- Low revenue collections: is forcing states to approach the 15 th finance commission to extend the compensation tenure beyond Fy2022

- Unearthing Of Input Tax Credit Frauds: has led to the introduction of stringent certification norms. there by delaying refunds

- Dalay In Refunds : is creating human omtervemtion, leading to potential for corruption, it is also shrinking the working cpital of smaller companies

- There Is No Consensus On Vital Issues: such as cutting rate slabs and bringing excluded items such as petroleum products and electricity under GST ambit

Impact of GST on Manufacturers, Distributor, and Retailers GST is a boost competitiveness and performance in India's manufacturing sector. Declining exports and high infrastructure spending are just some of the concerns of this sector. Multiple indirect taxes had also increased the administrative costs for manufacturers and distributors and with GST in place, the compliance burden has eased and this sector will grow more strongly.But due to GST business which was not under the tax bracket previously will now have to register. This will lead to lesser tax evasion.
IMPACT OF GST ON SERVICE PROVIDERS :

As of March 2014, there were 12,76,861 service tax assesses in the country out of which only the top 50 paid more than $50 \%$ of the tax collected nationwide. Most of the tax burden is borne by domains such as IT services, telecommunication services, the Insurance industry, business support services, Banking and Financial services, etc. These pan-India businesses already work in a unified market and will see compliance burden becoming lesser. But they will have to separately register every place of business in each state.

\section{Sector-wise Impact Analysis} LOGISTICS:

In a vast country like India, the logistics sector forms the backbone of the economy. We can fairly assume that a well organized and mature logistics industry has the potential to leapfrog the "Make In India" initiative of the Government of India to its desired position.

\section{E-COMMERCE:}

The e-commerce sector in India has been growing by leaps and bounds. In many ways, GST will help the e-com sector's continued growth but the long-term effects will be particularly interesting because the GST law specifically proposes a Tax Collection at Source (TCS) mechanism, which e-com companies are not too happy with. The current rate of TCS is at $1 \%$.

\section{PHARMA:}

On the whole, GST is benefiting the pharma and healthcare industries. It will create a level playing field for generic drug makers, boost medical tourism and simplify the tax structure. If there is any concern whatsoever, then it relates to the pricing structure.

\section{TELECOMMUNICATIONS:}

In the telecom sector, prices will come down after GST. Manufacturers will save on costs through efficient management of inventory and by consolidating their warehouses. Handset manufacturers will find it easier to sell their equipment as GST has negated the need to set up statespecific entities, and transfer stocks.

\section{TEXTILE}

The Indian textile industry provides employment to a large number of skilled and unskilled workers in the country. It contributes about $10 \%$ of the total annual export, and this value is likely to increase under GST.

\section{REAL ESTATE}

The real estate sector is one of the most pivotal sectors of the Indian economy, playing an important role in employment generation in India. The impact of GST on the real estate sector cannot be fully assessed as it largely depends on the tax rates.

\section{AGRICULTURE}

The agricultural sector is the largest contributing sector the overall Indian GDP. It covers around 16\% of Indian GDP. One of the major issues faced by the agricultural sector is the transportation of agri-products across state lines all over India.

\section{FMCG}

The FMCG sector is experiencing significant savings in logistics and distribution costs as the GST has eliminated the need for multiple sales depots.

\section{FREELANCERS}

Freelancing in India is still a nascent industry and the rules and regulations for this chaotic industry are still up in the air. But with GST, it will become much easier for freelancers to file their taxes as they can easily do it online. 
AUTOMOBILES

The automobile industry in India is a vast business producing a large number of cars annually, fueled mostly by the huge population of the country. Under the previous tax system, there were several taxes applicable to this sector like excise, VAT, sales tax, road tax, motor vehicle tax, registration duty which will be subsumed by GST.

\section{STARTUPS}

With increased limits for registration, a DIY compliance model, tax credit on purchases, and a free flow of goods and services, the GST regime truly augurs well for the Indian startup scene.

\section{COMPARASITION OF GST COLLECTIONS IN THE YEAR 2018-19 AND 2019-20}

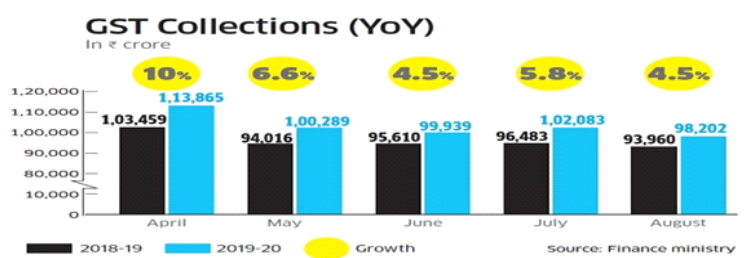

According to Goods and Services (Compensation to States) Act, 2017, if a state's revenue growth falls below $14 \%$ in a year, the Centre would bridge the shortfall for the first five years. The compensation is paid to the states once every two months out of a cess collected on taxes on sin and luxury goods. The Centre's compensation to states in June-July .. 2019, stood at Rs 27,955 crore.The second major challenge that the GST is facing today could potentially drag down total revenue. Early this week, the Directorate General of GST Intelligence unearthed a Rs 400 crore fraud of overvaluing and faking invoices to claim refund of input tax credit.We have decided to introduce stringent mechanism including linkage of Aadhaar to checkmate fake invoices and fraudulent refund claims.

\section{CONCLUSITION}

GST is the most logical steps towards the comprehensive indirect tax reform in our country. Since independence GST will give more relief to final consumers, industry, trade and agriculture through a more comprehensive and wider coverage of input tax set-off and service tax set-off, subsuming of several Central and State taxes in the GST and phasing out of CST. The subsuming of major Central and State taxes in GST would reduce the cost of locally manufactured goods and services. This is likely to increase the competitiveness of Indian goods and services in the international market and to boost Indian exports. GST would bring down the cascading \& Tax burden on final consumers, prices will also fall, Consumption and Demand would go up, investment would increase and as a result GDP would go up. A higher GDP would result in higher Tax revenues (higher tax GDP ratio) which will bring down fiscal deficit to half its size and revenue deficit to zero. Besides GST would integrate Indian economy with rest of the world as more than 130 countries already have GST in place. There are a few caveats in the analysis, which are important to highlight. First, this is a static model and hence, the impact of the GST should be interpreted as a long run effect. Second, the model is unable to address services trade which has become an important component of both domestic and international trade. In fact, the expected tax rate on services is higher than the current tax rate on services, which could therefore dampen the overall effects. Third, this note does not evaluate the impact on tax revenues. Even though the model predicts a decrease in tax revenue, there are reasons to believe that the GST could be revenue neutral. the Welfare Gains from Transportation Infrastructure: Evidence from the Golden Quadrilateral of India," Working paper.

3. Atkin, D. and D. Donaldson (2014): (Who's Getting Globalized? The Size and Impact of Intra-national Trade Costs," NBER Working Paper No. 21439.

4. Regional Outcomes," American Economic Journal: Microeconomics, 8, $24\{56$.

5. Sekhar, S. S. (2012). Goods and Services Tax-A Roadmap for India. In International Conference on Law, Humanities and Management, (ICLHM 2012) July (pp. 15-16).

6. Jain, A. (2013). An Empirical Analysis on Goods and Service Tax in India: Possible Impacts, Implications and Policies. International Journal of Reviews, Surveys and Research, 2(1)

7. Garg, Girish (2014), "Basic Concepts and Features of Good and Service Tax in India", International Journal of Scientific Research and Management, volume 2 issue 2 .

8. Shah, Kumar (2014), "Goods and Service (GST) Tax in India: Challenges and Opportunities",Global Journal of Multidisciplinary Studies, volume 3, issue 9

\section{REFERENCES}

1. Alder, S. (2017): \Chinese Roads in India: The Effect of Transport Infrastructure on Economic Development, "Working paper.

2. Asturias, J., M. Garcff_a-Santana, and R. Roberto (2016): \Competition and 